\title{
Botanicals to Cope Stored Grain Insect Pests: A Review
}

\author{
Manohar Lal', Budhi Ram ${ }^{2}$ and Prabhat Tiwari ${ }^{3 *}$ \\ ${ }^{1}$ Departement of Seed Science and Technology, Dr. YS Parmar University of \\ Horticulture and Forestry, Nauni, Solan (HP)-173 230, India \\ ${ }^{2}$ Departement of Entomology, Dr. YS Parmar University of Horticulture and \\ Forestry, Nauni, Solan (HP)-173 230, India \\ ${ }^{3}$ Departement of Silviculture and Agroforestry, Dr. YS Parmar University of \\ Horticulture and Forestry, Nauni, Solan (HP)-173 230, India \\ *Corresponding author
}

\section{Keywords \\ Botanicals, \\ Ecosystem, \\ Environment, \\ Grains or seeds, \\ Storage insect pests, \\ Synthetic pesticides. \\ Article Info \\ Accepted: \\ 21 May 2017 \\ Available Online: \\ 10 June 2017}

\section{A B S T R A C T}

The present article has been reviewed to know the importance of different plant products (botanicals) against storage insect pests of seeds and grains. Storage of grains is very important in agriculture for next generation and for food security. Among various biotic and abiotic factors which determine fate of grains during storage, insect pests are of economic importance as they cause significant loss. By reducing or eliminating the insect pest population while storage the rising demands of the increasing population of the world can be fulfilled. Among various storage insect pests Sitotroga cerealella, Sitophilus sp., Rhyzopertha Dominica, Trogoderma granarium, Tribolium sp., Callosobruchus sp. etc. are most detrimental. Insect damages include consumption of seed, debris of exuviae, webbing, and cadavers thereby makes the grain unfit for human consumption and also reduce quality as well as quantity. They manipulates storage environment resulted in development of hotspots which are congenial for the proliferation of storage fungi and other harmful micro flora. Conventionally we are exploiting synthetic pesticides to manage different insect pests which are hazardous to environment and ecosystem in various ways such as elimination of natural enemies; insect resistance and resurgence problem; making soil, water and air sick; have residual effects thereby cause different disorders or diseases to animals and humans. Biodegradable, non-residual, equally effective and easily available botanicals such as neem (Azadirachta indica), bach (Acorus calamus), phoolakri (Lantana camara), draik (Melia azadarach), kali mirch (Piper nigrum), Basuti (Adhatoda zeylanica) etc. may prove to be a better option to control insect pests including storage pests without affecting the quality of grains or seeds and without harming our ecosystem or environment. Thus botanicals may be recommended alone or as a part of IPM to control insect pests.

\section{Introduction}

Storage of the grains and seeds is very important in agriculture to start a new life and also in food security point of view. The quality grains and seeds during storage depends on various factors such as crop or variety, initial seed quality, storage conditions, seed moisture content, insect pests, bacteria and fungi (Amruta et al., 2015). Among these factor insect does a significant contribution to the total loss. Total 
productivity of agricultural crops of India is 3 tonnes/ha as compared to global average i.e. 4 tonnes/ha (Anonymous, 2015a); out of which loss due to insect pests is about $26 \%$ as shown in figure 1 (Anonymous, 2015b) and food grain accounts for $20-25 \%$ damage by storage insect pests (Rajashekar et al., 2010) which is really a brainstorming matter. Among various storage insect pests Angoumois grain moth (Sitotroga cerealella), maize/ rice weevil (Sitophilus oryzae), lesser grain borer (Rhyzopertha dominica), khapra beetle (Trogoderma granarium), rust-red flour beetle (Tribolium castaneum), legume weevil (Callosobruchus sp.) etc. are most detrimental (GC, 2006). With the increase in population the demand for the grains or other agricultural based products is also rising and by managing the loss due to storage insect pests we can fulfil the demand to some extent. Damage of grains due to poor ware housing facilities and damage by stored grain insect pests during storage, shipping and transportation, is very serious problem in South-East Asia and all over the globe (Upadhyay and Ahmad, 2011) especially in the developing countries (Talukder et al., 2004; Dubey et al., 2008). The insect pests not only damage the grain but also depreciate the weight and quality of stored grains (Rayhan, 2014). Insect damages include direct consumption of kernels, detritus of exuviae, webbing, and cadavers thereby makes the grain unfit for human consumption and also reduce quality and quantity. Insect infestation manipulate the storage environment resulted in development of hotspots which are congenial for the proliferation of storage fungi and other harmful micro flora (Rajashekar et al., 2012).

Today, pest control technology is mostly dependent on synthetic insecticides (Azad et $a l ., 2013)$. The chemical pesticides dominated in pest management programmes throughout the globe since the discovery of DDT in 1939 (Misra, 2014). In India use of synthetic pesticides started after the green revolution came into existence. Among various pesticides used in India insecticides alone have 65\% share (Anonymous, 2015c) as shown in figure 2. Pesticides and related issues remained a burning topic in media, debates, researches etc. since few decades. The different problems regarding residual effects, pest resurgence, prevalent environmental and ecological hazards, insect pest resistance and economy of farmers associated with currently used synthetic pesticides have directed us to botanicals (Zettler and Cuperus 1990; Elhag, 2000) which are environmental friendly, biodegradable, economic and are equally effective. Moreover, if grains are to be stored for food purpose pesticides sometimes prove to be poisonous or lethal. Plant products, such as aqueous or organic solvent extracts are being used in many countries as protectants of stored products (Fernando and Karunaratne, 2012).

Humans have used various plant metabolites for thousands of years in various ways such as dyes (e.g. indigo, shikonin), flavours (e.g. vanillin, capsaicin), fragrances (e.g. essential oils of rose, lavender), stimulants (e.g. caffeine, nicotine), hallucinogens (e.g. morphine, tetrahydrocannabinol), poisons (e.g. strychnine, coniine) and medicines (e.g. quinine, atropine) (Joseph et al., 2012). Biological products of the plants may affect activities of the different arthropods including storage pests. Plants having some insecticidal properties have been exploited since long past to protect stored products from insect pests (Belmain and Stevenson, 2001). Some of the metabolites of plants are toxic such as pyrethrum, nicotine, rotenone etc. and some are repellents, antifeedants like azadirachtin, rape seed extract and others, like Acorus calamus act as sterilants (Ignatowicz and Wesolowska, 2015). Asian countries have abundant of these plant products which are 
traditionally used by the rural residents for preparations against insect control (Talukder and Howse, 1993). Therefore these plant products may be utilized either alone or as a part of integrated pest management. Moreover, since the pesticides came into existence the botanicals have been ignored; research and development focused on synthetic pesticides. Therefore research needs to be done to explore and exploitation of botanicals for pest management. Considering above problems and facts the present article has been reviewed under the following subheads.

\section{Effect of synthetic pesticides on environment and ecology}

Although pesticides are considered as a quick, easy, and inexpensive solution for controlling insect pests but they have polluted almost all the places and their residues found in soil and air and water all over the globe. Pesticides released into the environment may have longterm or short-lived effects in the normal functioning of an ecosystem (Zacharia, 2011). Regular and indiscriminate use of pesticides not only affected the environment and agriculture but also has entered in our food chain thereby affecting health and development of animals and human race (Rajendran, 2003). Synthetic pesticides along with the insect pest of economic importance also kill beneficial natural enemies and other organisms; thereby enhance pest problems as they are important in pest control. Among various pesticides, insecticides are generally the most acutely toxic class (Aktar et al., 2009). Residual effect of insecticides was reported on natural enemies in which the suppressive effect was pronounced on the parasitic wasps that attack the obscure scale (Melanaspis obscura), a common scale insect pest of oak (Raupp et al., 2001). Different arsenic derivates present in paddy soil were detected which appear to check the growth of rice $(\mathrm{Li}, 1983)$.
Persistence of pesticide in water, soil, air and food material poses a serious threat to living beings including humans. Pesticides leached out from crop land to various water bodies through water drainage by rain or irrigation (Larson et al., 2010) thereby constituting a problem for the supply of drinking water to the population (Aktar et al., 2009). Some of the volatile pesticides are serious risk to atmospheric pollution (Trajkovska et al., 2009) which may cause various respiratory or allergic problems. The effects of the different pesticides are directly reflected from soil properties and soil micro-flora through which these pesticides undergoes degradation, transport and other various process (Hussain et al., 2009). Organic soil without the use of chemicals (pesticides) results in improved soil health and quality (Johnson, 1986), and increased organic matter in the soil improves water holding capacity (Zacharia, 2011).

These pesticides when consumed directly or indirectly may cause serious disorders in living beings. Depending upon toxicity and exposure (length and magnitude) the pesticides have more hazardous effects on the human beings (Lorenz, 2009). Latest example is neoplasmic growth and respiratory problems observed in humans in Kerala due to the excessive and indiscriminate use of endosulphan which was banned later. The residues present in various leafy vegetables causes disorders like neural tube defect (NTD) among newborn children; in human (breast) milk and cow milk resulted in diseases like cancer, epilepsy, skin diseases and unbearable suffering (Rajendran, 2003). On the other hand natural pesticides have no such side effects and are biodegradable (Upadhyay and Ahmad, 2011). In the field also, the reduced use of pesticides and sustainable agriculture management practices protects our national pollinator resources (Mader and Adamson, 2012), which are very important for cross pollinated plants. Botanical are detrimental only to target pests, 
are effective in very small quantities, degrade rapidly and provide pesticide free food and a safe environment for living beings (Joseph et al., 2012). Therefore botanicals should be included in the pest management practices and pesticides should not be applied to the limit that is hazardous to environment and ecology.

\section{Insect resistance and resurgence}

Resistance in insects is their ability to bear up doses of toxic substances that would be fatal to normal individuals or insects (Obeng, 2010) and resurgence is reappearance and increase of pests to a destructive level. Nonsystematic and regular application of pesticides (insecticides) resulted reduction in their efficiency to control storage insect pests (Subramanyam and Hagstrum, 1996) due to genetic alterations in them. Many insect pests are very susceptible to pesticides initially, but due to alteration in their genetic constitution or through natural selection they become resistant and are able to reproduce (Zacharia, 2011). Also, regular use of pesticides especially broad spectrum kills the natural enemies and thereby increases the insect pests. Where insect pests have some controls from a beneficial predator or parasite, application of insecticides can eliminate both pests and beneficial insects (Zacharia, 2011). Insecticides sometimes eliminates primary pest provides opportunity to the secondary pests to become primary pests (Dhaliwal et al., 2006) i.e. an increase in damage from such species were not originally very hazardous due to loss of their natural enemies. About one-third population of most damaging insects in the US was secondary pests earlier and became primary due to indiscriminate use of pesticides (Miller, 2004).

Fig.1 Crop yield losses due to insects and other pests in India

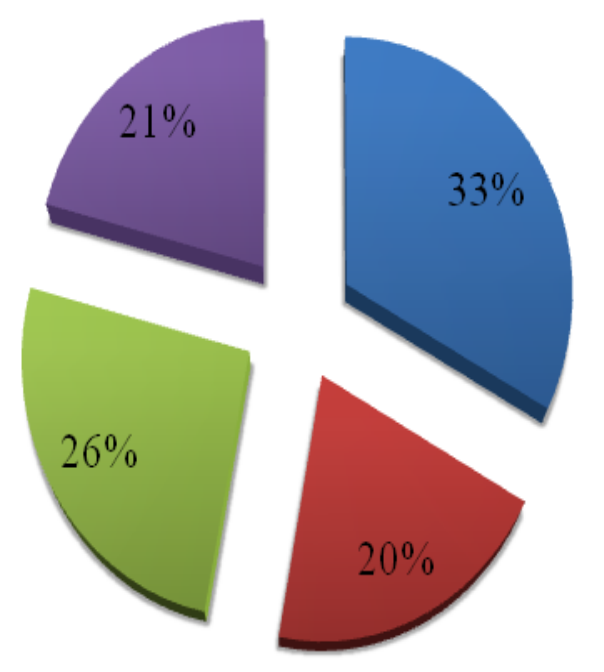

- Weeds

Diseases

Insects

Others

(Source: Directorate of Weed Research, Jabalpur (MP)) 
Fig.2 Pesticide use pattern in India

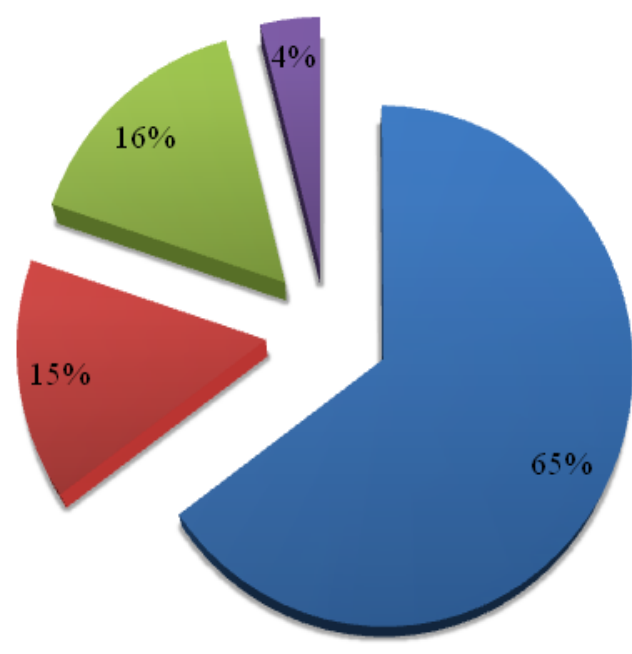

- Insecticides

- Fungicides

- Herbicides

- Others

(Source: Krishi Jagran / By: KJ News / Updated: January 9, 2015 13:39 IST)

Fig.3 Pesticide use trends over the years in India

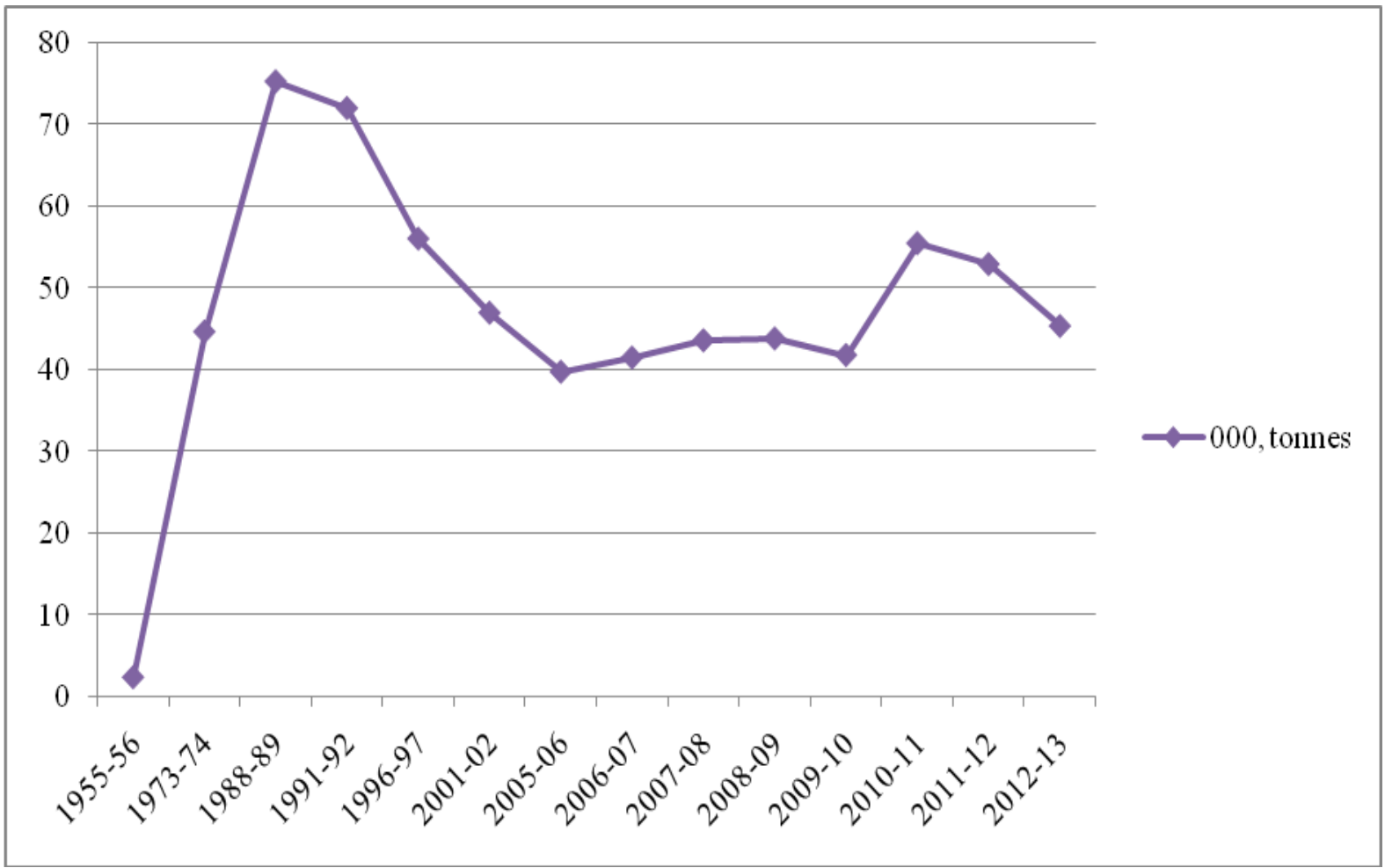

(Source: Krishi Jagran / By: KJ News / Updated: January 9, 2015 13:39 IST) 
Table.1 List of some of the botanicals to manage different storage insects

\begin{tabular}{|c|c|c|c|c|}
\hline S.No. & Plants (source) & Product & Target storage pests & References \\
\hline 1 & $\begin{array}{l}\text { Clerodendrum inerme, } \\
\text { Withania somnifera }\end{array}$ & Ethanol extract & Sitophilus oryzae & Yankanchi and Gadache, 2010 \\
\hline 2 & Withania somnifera & Petroleum extract & Callosobruchus chinensis & Gupta and Srivastava, 2008 \\
\hline 3 & $\begin{array}{l}\text { Eucalyptus sp., Lantana } \\
\text { camara, Azadirachta } \\
\text { indica }\end{array}$ & Ethanol extract & Sitophilus zeamais & Mulungu et al., 2007 \\
\hline 4 & Clerodendrum $s p$. & Ethanol extract & Sitophilus oryzae & Roychoudhary, 1994 \\
\hline 5 & Olax zeylanica & Leaf powder & Sitophilus oryzae & Fernando and Karunaratne, 2012 \\
\hline 6 & Acorus calamus & Rhizome powder & $\begin{array}{l}\text { Rhizopertha } \\
\text { dominica, Sitophilus } \\
\text { oryzae }\end{array}$ & $\begin{array}{l}\text { Biradar, 2000; } \\
\text { Channabasanagowda et al., 2008; } \\
\text { Sandeep et al.,2013 }\end{array}$ \\
\hline 7 & Azadirachta indica & NeemAzal & Sitophilus zeamais & Nukenine et al.,2011 \\
\hline 8 & Azadirachta indica & Azadirachtin & Sitophilus oryzae & Athanassiou et al., 2005 \\
\hline 9 & Azadirachta indica & NeemAzal & Prostephanus truncates & Ogemah et al., 2002. \\
\hline 10 & $\begin{array}{l}\text { Chenopodium } \\
\text { ambrosioides, } \\
\text { Azadirachta indica }\end{array}$ & Leaf powder & Zabrotes subfasciatus & Araya and Emana, 2009 \\
\hline 11 & Piper nigrum & Seed powder & Sitophilus zeamais & Issa et al., 2011 \\
\hline 12 & $\begin{array}{l}\text { Lantana camara, } \\
\text { Tephrosia vogelii }\end{array}$ & Plant powder & Sitophilus zeamais & Ogendo et al., 2004 \\
\hline 13 & Lantana camara. & $\begin{array}{l}\text { Petroleum ether } \\
\text { extract }\end{array}$ & Callosobruchus chinensis & Pandey et al., 1986 \\
\hline 14 & Azadirachta indica & $\begin{array}{l}\text { Plant powder } \\
\text { extract }\end{array}$ & Sitophilus oryzae & Devi et al., 2014 \\
\hline 15 & $\begin{array}{l}\text { Melia azadarach, } \\
\text { Calotropis procera }\end{array}$ & $\begin{array}{l}\text { Leaves, bark and } \\
\text { seeds powder }\end{array}$ & $\begin{array}{l}\text { Rhizopertha } \\
\text { Dominica }\end{array}$ & $\begin{array}{l}\text { Khan and Marwat, } \\
2004\end{array}$ \\
\hline 16 & $\begin{array}{l}\text { Azadirachta indica, } \\
\text { Swietenia mahagoni }\end{array}$ & Plants' seed oils & Sitophilus oryzae & Rayhan et al., 2014 \\
\hline 17 & $\begin{array}{l}\text { Helianthus annuus, } \\
\text { Gossypium spp., Olea } \\
\text { europaea, Sesamum } \\
\text { orientale, Glycine max, } \\
\text { Brassica napus } \\
\end{array}$ & Plant oils & $\begin{array}{l}\text { Callosobruchus } \\
\text { maculates }\end{array}$ & Ibrahim, 2012 \\
\hline 18 & $\begin{array}{l}\text { Cassia senna, } \\
\text { Caesalpinia gilliesii, } \\
\text { Thespesia populnea var. } \\
\text { acutiloba, } \\
\text { Chrysanthemum } \\
\text { frutescens, Euonymus } \\
\text { japonicus, Bauhinia } \\
\text { purpurea, Cassia fistula }\end{array}$ & Methanol extract & Trogoderma granarium & Derbalah, 2012 \\
\hline 19 & Adhatoda zeylanica & $\begin{array}{l}\text { Leaf extract and } \\
\text { methanol extract }\end{array}$ & $\begin{array}{l}\text { Callosobruchus } \\
\text { Chinensis, C.maculatus }\end{array}$ & Misra, 2014 \\
\hline 20 & Annona reticulata & $\begin{array}{l}\text { Root, stem, leaves } \\
\text { and seeds extract }\end{array}$ & $\begin{array}{l}\text { Tribolium } \\
\text { Castaneum }\end{array}$ & Misra, 2014 \\
\hline 21 & Clerodendron inermi & $\begin{array}{l}\text { Petroleum ether } \\
\text { leafextract }\end{array}$ & $\begin{array}{l}\text { Callosobruchus } \\
\text { Chinensis }\end{array}$ & Misra, 2014 \\
\hline 22 & Ageratum conyzoides & $\begin{array}{l}\text { Leaf, flower and } \\
\text { root extracts }\end{array}$ & Tribolium castaneum & Misra, 2014 \\
\hline 23 & Acorus calamus & Rhizome powder & $\begin{array}{l}\text { Sitophilus zeamais, } \\
\text { Sitophilus oryzae }\end{array}$ & GC, 2006 \\
\hline 24 & $\begin{array}{l}\text { Artemisia roxburghii, } A \text {. } \\
\text { annua, Mentha } \\
\text { longifolia, } \text { M. Spicata } \\
\text { Tagetus erecta, Melia } \\
\text { azedarach }\end{array}$ & Aqueous extracts & Callosobruchus chinensis & Rana et al., 2014 \\
\hline
\end{tabular}


Now, due to these problems, widespread environmental hazards and increasing costs the application of pesticides for the control of storage insect pests has been reduced (Bekele et al., 1995; Bekele, 2002) all over the world along with India as shown in figure 3 . Botanicals can be better option for management of insect pests as these degrade rapidly and do not give the chance to gain genetic resistance in the insect pests. If it is necessary to apply pesticides, should be applied in rotation i.e. use same pesticide every time should be avoided; or inclusion of botanicals may be done with the limited doses of insecticides.

\section{Importance of botanicals in integrated pest management (IPM)}

Pest management including postharvest infestation through integrated pest management (IPM) is now become an effective and most accepted approach (Rajashekar et al., 2010). IPM approach is very effective way to prevent the development of resistance which emphasizes the judicial use of non-chemical methods (botanicals, light traps, natural enemies) and selective synthetic applications (Obeng, 2010). Integrated pest management signifies judicial and effective use available resources (Natural or synthetic) for the pest management without harming the ecological balance. Extensive use of synthetic pesticide should not be permitted or may be used with botanicals as a part of IPM to control the insect pests. Amruta et al., (2015) recorded effective storage insect control and higher seed quality when treated with botanicals and emamectin benzoate. Insecticidal plant extracts have broad spectrum action and easy to prepare in farm levels (Azad et al., 2013) from the locally available material. Other researchers, Nukenine et al., (2011) reported that neem based viz. Neem Azal and NSO (neem seed oil) had sufficient efficacy against
S. Zeamais to be a component of an integrated management. Another neem product Azadirachtin causes $100 \%$ mortality to Sitophilus oryzae (Athanassiou et al., (2005). Some of the important botanicals to control or supress various storage insect pests like Sitophilus oryzae, S. Zeamais, Callosobruchus chinensis, C. maculates, Tribolium castaneum, Rhizopertha dominica, Trogoderma granarium etc. has been listed in table 1. Botanicals converted to harmless metabolites rapidly and do not help to build up inherited confrontation in targeted pests and are less detrimental to other beneficial organisms. Thus different botanicals can be used effectively to treat grains (Obeng, 2010) depending upon the locations as activity of botanicals varies across geographical locations (Kaushik et al., 2007; Abdalla et al., 2010); even with differences in storage durations and conditions. From the findings of different researchers we can say that botanicals may be effectively used in the integrated pest management (IPM) programme.

\section{Effect of biopesticides (botanicals) on seed quality}

Seed quality is determined by various biotic and abiotic factors such as genotype, moisture content of seed, storage conditions and pests like fungi, bacteria, insects etc (Amruta et al., 2015). While we are storing the seeds for sowing purpose in the coming season or year, the viability and health is most important. Maintenance of seed quality during storage is essential for successful crop production and for maintaining integrity of the seeds that are prone to unpredictable threat of genetic erosion (Barua et al., 2009). The infestation of seeds due to storage insect pests leads to loss of viability and vigour thereby affecting germination adversely (Rana et al., 2014). Findings of different researchers showed that botanicals did not have unfavourable effect on 
germination value of the seeds (Gupta et al., 1988; Pandey et al., 1986; Khaire et al., 1992). The killing or repellent property of various botanicals makes seeds unsuitable for insect pests during storage (Prakash and Jagadishwari, 1992) and enhance the quality parameters (germination, viability, vigour); but according to Kasa and Tadese (1995) use of botanical to manage $S$. zeamais in sorghum did not have any effect on seed germination. Botanicals might have the phytotonic effect thereby increase seed quality parameters Sandeep et al., (2013); recorded higher germination, vigour index and less infestation during storage when maize seeds treated with sweet flag rhizome powder. Channabasanagowda et al., (2008), Keshavulu and Krishnasamy (2005), and Khatun et al., (2011) recorded similar results with botanicals in different crops. Therefore farmers may use botanicals for the management of stored grain pests without any adverse effect on germination (Mamun and Shahjahan, 2011; Ogendo et al., 2004), viability and vigour of the treated seeds.

After reviewing findings of different researchers it can be concluded that storage insect pest such as Sitophilus sp., Callosobruchus sp., Tribolium castaneum, Rhizopertha Dominica, Trogoderma granarium etc. does great loss and which needs to be control to feed the bursting population on this earth. Conventionally we are exploiting synthetic pesticides to manage different insect pests which are hazardous to environment and ecology in various ways such as eliminating natural enemies; insect resistance and resurgence problem; making soil, water and air sick; have residual effects which cause different disorders or diseases to animals and humans. Therefore biodegradable, non-residual, equally effective and easily available botanicals may prove to be a better option to control insect pests including storage pests without affecting the quality of grains or seeds. Thus botanicals may be recommended alone or as a part of IPM to control insect pests.

\section{References}

Abdalla, A.S., Mohamed, E.E. and Abdin, E.M. 2010. Insecticidal activities of neem (Azadirachta indica A. Juss) seeds under laboratory and field conditions as affected by different storage durations. Agric. Biol. J. Am., 5:1001-1008.

Aktar, M.W., Sengupta, D. and Chowdhury, A. 2009. Impact of pesticides use in agriculture: their benefits and hazards. Interdiscipl. Toxico, 2(1): 1-12.

Amruta, N., Sarika, G., Umesha, Maruthi, J.B. and Basavaraju, G.V. 2015. Effect of botanicals and insecticides seed treatment and containers on seed longevity of black gram under natural ageing conditions. J. App. Nat. Sci., 7 (1): $328-334$.

Anonymous. 2015a. ushering in the 2nd green revolution: Role of crop protection chemicals. A report on agrochemical industry, FICCI. 51p.

Anonymous. 2015b. Vision 2050. Directorate of Weed Research (ICAR), Jabalpur (MP), 32p.

Anonymous. 2015c. Outlook of pesticide consumption in India. Krishi Jagran / By: KJ News / Updated: January 9, 2015 13:39 IST

Getu, E. 2009. Evaluation of botanical plants powders against Zabrotes subfasciatus (Boheman) (Coleoptera: Bruchidae) in stored haricot beans under laboratory condition. Afr. J. Agricult. Res., 4(10): 1073-1079.

Athanassiou, C.G., Kontodimas, D.C., Kavallieratos, N.G. and AnagnouVeroniki, M. 2005. Insecticidal effect of NeemAzal against three stored-product 
beetle species on rye and oats. J. Eco. Entom., 98:1499-1505.

Azad, A.K., Sardar, A., Yesmin, N., Rahman, M. and Islam, S. 2013. Eco-friendly pest control in cucumber (Cucumis sativa L.) field with botanical pesticides. Nat. Reso., 4(5): 6p.

Barua, H., Rahman, M.M., Masud, M.M. 2009. Effect of storage container's environment at different storage period on the quality of chilli seeds. Int. J. Sust. Crop Prod., 4(4):28-32.

Bekele, A.J., Ofori, D.O. and Hassanali, A. 1995. Products derived from the leaves of Ocimum kilim and Scharicum (Labiatae) as post-harvest grain protectants against the infestation of three major stored product insect pests. Bull. Entomol. Res., 85: 361-367.

Bekele, J. (2002). Evaluation of the toxicity potential of Milletia ferruginea (Hochest) Baker against Sitophilus zeamais (Motsch.). Int. J. Pest Manag, 48: 29-32.

Belmain, S., and Stevenson, P. 2001. Ethnobotanicals in Ghana: reviving and modernizing age old farmer practice. Pest. Out, 12:233-38.

Biradar. B.S. 2000. Prevention of cross infestation by Sitophilus oryzae Linn and Rhizopertha dominica Fab. In: Stored wheat. M.Sc. (Ag.) Thesis, University of Agricultural Sciences, Dharwad, Karnataka (India).

Gowda, C., Biradar Patil, N.K., Ninganur, B.T., Patil, B.N., Hunje, R. and Awaknavar, J.S. 2008. Effect of botanical seed treatment on storability of wheat. Kar. J. Agric. Sci., 21(3):361365.

Derbalah, A.S. 2012. Efficacy of some botanical extracts against Trogoderma granarium in wheat grains with toxicity evaluation. Sci. World J., doi: 10.1100/2012/639854.
Devi, M.B., Devi, N.V. and Singh, S.N. 2014. Effects of six botanical plant powder extracts on the control of rice weevil, Sitophilus oryzae L. in stored rice grains. Int. J. Agri. Inno. Res., 2 (5): 683-686.

Dhaliwal, G.S., Singh, R. and Chhillar, B.S. 2006. Essentials of agricultural entomology. Kalyani Publishers, New Delhi, India.

Dubey, N.K., Srivastava, B. and Kumar, A. 2008. Current status of plant products as botanical pesticides in storage pest management. J. Biopest, 1(2): 182-186.

Elhag, E.A. 2000. Deterrent effects of some botanical products on oviposition of the cowpea bruchid Callosobruchus maculates (F.) (Coleoptera: Bruchidae). Int. J. Pest Manag., 46(2): 109-113.

Fernando, H.S.D. and Karunaratne, M.M.S.C. 2012. Ethnobotanicals for storage insect pest management: Effect of powdered leaves of Olax zeylanica in suppressing infestations of rice weevil Sitophilus oryzae (L.) (Coleoptera: Curculionidae). J. Trop. For. Environ., 2(1): 20-25.

Gc, Y.D. 2006. Efficacy of indigenous plant materials and modified storage structures to insect pests of maize seed during on-farm storage. J. Inst. Agric. Ani. Sci., 27:69-76.

Gupta, H.C., Verma, J.P., Bareth, S.S. and Mathur, B.N. 1988. Evaluation of some non-edible oils as grain protectant in wheat and their subsequent effect on germination. Ind. J. Entom., 50(2): 147150.

Gupta, L. and Srivastava, M. 2008. Effect of Withania somnifera extracts on the mortality of Callosobruchus chinensis L. J. Biopest., 1(2): 190- 192.

Hussain, S., Siddique, T., Saleem, M., Arshad, M. and Khalid, A. 2009. Impact of pesticides on soil microbial diversity, enzymes, and biochemical reactions. Adv. Agron., 102:159-200. 
Ibrahim, M.Y. 2012. Efficacy of some plant oils against stored-product pest cowpea weevil, Callosobruchus maculatus (Coleoptera: Bruchidae) on chickpea seeds. Per. Gu. Crop Prot., 1(1): 4-11.

Ignatowicz, S. and Wesolowska, B. 2015. Potential of common herbs as grain protectants: repellent effect of herb extracts on the granary weevil, Sitophilus granarius L. Proceedings of 6th International Working Conference on Stored-products Protection, 2: 790794.

Issa, U.S., Afun, J.V.K., Mochiah, M.B., Owusu-Akyaw, M. and Braima, $\mathrm{H}$. 2011. Effect of some local botanical materials for the suppression of weevil populations. Int. J. Plant, Ani. Envir. Sci., 1(3): 270-275.

Johnson, A.E. 1986. Soil organic-matter, effects on soils and crops. Soil Use Man., 2: 97-105.

Joseph, B., Sowmya and Sujatha, S. 2012. Insight of botanical based biopesticides against economically important pest. Int. J. Phar. Life Sci., 3(11): 2138-2148.

Kasa, A. and Tadese, A. 1995. Evaluation of some botanicals against the maize weevil, Sitophilus zeamais Motsch., on stored sorghum at Bako. In: Bekele E, Abdulahi A, and Yemane A (eds.), Proceeding of 3rd annual conference of the crop protection society of Ethiopia, May 18-19, 1995, Addis Abeba, Ethiopia. CPSE, 120-126.

Kaushik, N., Singh, B.G., Tomar, U.K., Naik, S.N., Satya, V., Bisla, S.S., Sharma, K.K., Banerjee, S.K. and Thakkar. P. 2007. Regional and habitat variability in azadirachtin content of Indian neem (Azadirachta indica A. Jusieu). Curr. Sci., 92:1400-1406.

Keshavulu, K. and Krishnasamy, V. 2005. Effect of seed colouring on seed quality and bruchid damage in soybean. Seed Res., 33(2): 208-210.
Khaire, V.M., Kachare, B.V. and Mote, U.N. 1992. Efficacy of different vegetable oils as grain protectants against Pulse beetle, Callosobruchus chinensis L. in increasing storability of pigeon pea. $J$. Stor. Prod. Res., 28(3): 153-156.

Khan, S.M. and Marwat, A.A. 2004. Effect of bakain (Melia azadirach) and $\mathrm{Ak}$ (Calotropis procera) against lesser grain borer (Rhyzopertha dominica F). J. Res. (Sci.) Bahauddin Zakariya University Multan, 15: 319-324.

Khatun. A., Kabir, G., Bhuiyan, M.A.H. and Khanam, D. 2011. Effect of preserved seeds using different botanicals on seed quality of lentil. Ban. J. Agric. Res., 36(3): 381-387.

Larson, S.J., Capel, P.D., Majewski, M. 2010. Pesticides in surface waters: Distribution, trends, and governing factors. CRC Press.

Li, G.C. 1983. Residue and toxicity problems associated with pesticide use in Taiwan. Tropical Agriculture Research Center, Ministry of Agriculture, Forestry and Fisheries, Yatabe, Tukuba, Ibaraki, 305 Japan, Pp. 165-177.

Lorenz, E.S. 2009. Potential Health Effects of Pesticides. Agric. Comm. and Mark, 1-8 Pp.

Mader, E. and Adamson, N.L. 2012. Organicapproved pesticides: Minimizing risks to bees. The Xerces Society for Invertebrate Conservation, Pp. 1-6.

Mamun, M.S.A. and Shahjahan, M. 2011. Effect of some indigenous plant extracts on the germination of wheat seeds. Ban. J. Agric. Res., 36(4): 733-739.

Miller, G.T. 2004. Sustaining the Earth, 6th edition. Thompson Learning, Inc. Pacific Grove, California, USA.

Misra, H.P. 2014. Role of botanicals, biopesticides and bioagents in integrated pest management. Odisha Rev., Pp. 62-67. 
Mulungu, L.S., Lupenza, S.O., Reuben, O.W. and Misangu, R.N. 2007. Evaluation of botanical products as stored grain protectant against Maize weevil, Sitophilus zeamays. J. Ent., 4(3): 258262.

Nukenine, E.N., Tofel, H.K. and Adler, C. 2011. Comparative efficacy of Neem Azal and local botanicals derived from Azadirachta indica and Plectranthus glandulosus against Sitophilus zeamais on maize. J. Pest Sci., 84: 479-486.

Obeng-Ofori, D. 2010. Residual insecticides, inert dusts and botanicals for the protection of durable stored products against pest infestation in developing countries. 10th International Working Conference on Stored Product Protection, Section: Residual Insecticides - Synthetic and Botanical: 474-478.

Ogemah, V., Reichmuth, C. and Buttner, C. 2002. Effect of NeemAzal and other neem products on mortality, fecundity and frass activity of the larger grain borer Prostephanus truncatus (Horn) (Coleoptera: Bostrichidae) infesting maize. In: Proceedings of the 8th international work conference on stored product protection, York, 588-594 Pp.

Ogendo, J.O., Deng, A.L., Belmain, S.R., Walker, D.J. and Musandu, A.A.O. effect of insecticidal plant materials, Lantana camara and Tephrosia vogelii, on the quality parameters of stored maize grains. J. Food Tech. Afr., 9: 2936.

Pandey, N.D., Mathur, K.K., Pandey, S. and Tripathi, R.A. 1986. Effects of some plant extracts against pulse beetle, Callosobruchus chinensis Linnaeus. Ind. J. Ent., 48(1): 85-90.

Prakash A. and Rao, J. 1992. Deltamethrin, a paddy seed protectant against insects under natural storage conditions. Bull. Green Techn, 30: 113-118.
Rajashekar, Y., Gunasekaran, N., and Shivanandappa, T. 2010. Insecticidal activity of the root extract of Decalepis hamiltonii against stored product insect pests and its application in grain protection. J. Food Sci. Tech, 47(3): 310-314.

Rajashekar, Y., Bakthavatsalam, N. and Shivanandappa, T. 2012. Botanicals as grain protectants. Psyche: A J. Ento, 13 Pp.

Rajendran, S. 2003. Environment and health aspects of pesticides use in Indian agriculture. In: Martin J. Bunch, V. Madha Suresh and T. Vasantha Kumaran, (Eds), Proceedings of the Third International Conference on Environment and Health, Chennai, India, 15-17 December, 2003. Chennai: Department of Geography, University of Madras and Faculty of Environmental Studies, York University, Pp. 353-373.

Rana, K., Sharma, K.C. and Kanwar, H.S. 2014. Efficacy of aqueous plant extracts on the seed quality of pea (Pisum sativum L.) during storage. Am. Int. J. Res. For., App. Nat. Sci., 6(1): 7-11.

Raupp, M.J., Holmes, J.J., Clifford, S.P., Shrewsbury, P. and Davidson, J.A. Effects of cover sprays and residual pesticides on scale insects and natural enemies in urban forests. J. Arbori., 27(4): 2013-214.

Rayhan, M.Z., Das, S., Sarka,r R., Adhikary, S.K., Tania, S.N., Islam, M.M. and Rabbani, M.G. 2014. Bioefficacy of neem, mahogoni and their mixture to protect seed damage and seed weight loss by rice weevil in storage. J. Biod. Env. Sci., 5(1): 582-589.

Roychoudhary, N. 1994. Antifeedant and insecticidal activities of Clerodendrum species against rive weevil. J. App. Zool. Res., 5(1): 13-16. 
Sandeep, D., Chandrashekhar, G.S., Ranganathswamy, M., Mallesh, S.B., Kumar, H.B.H. and Patibanda, A.K. 2013. Effect of botanicals on storability of sweet corn (Zea mays L. Saccharum) seeds. Int. J. Plant Prot., 6(1): 11-14.

Subramanyam, B. and Hagstrum, D.W. 1996. Resistance measurement and management. In: Integrated Management of Insects in Stored Products, Subramanyam, B. and Hagstrum, D.W. (Eds). Marcel Dekker, Inc. New York, USA: 331-397.

Talukder, F.A. and Howse, O.E. 1993. Deterrent and insecticidal effects of extracts of pithraj, Aphanamixis polystachya (Meliaceae) against Tribolium castaneum in storage. J. Chem. Eco., 19(11): 2463-2471.

Talukder, F.A., Islam, M.S., Hossain, M.S., Rahman, M.A. and Alam, M.N. 2004. Toxicity effects of botanicals and synthetic insecticides on Tribolium castaneum (Herbst) and Rhyzopertha dominica (F.). Bang. J. Env. Sci., 10 (2): 365-37.

Trajkovska, S., Mbaye, M., Seye, M.G., Aaron, J.J., Chevreuil, M., Blanchoud,
H. 2009. Toxicological study of pesticides in air and precipitations of Paris by means of a bioluminescence method. Anal. Bioan. Chem., 394: 10991106.

Upadhyay, R.K. and Ahmad, S. 2011. Management strategies for control of stored grain insect pests in farmer stores and public ware houses. World. J. Agric. Sci., 7 (5): 527-549.

Yankanchi, S.R. and Gadache, A.H. 2010. Grain protectant efficacy of certain plant extracts against rice weevil, Sitophilus oryzae L. (Coleoptera: Curculionidae). J. Biopest, 3(2): 511 513.

Zacharia, J.T. 2011. Ecological Effects of Pesticides. In: Pesticides in the Modern World - Risks and Benefits, Stoytcheva M (Ed.). InTech Publisher, 560 Pp.

Zettler, J.L. and Cuperus, G.W. 1990. Pesticide resistance in Tribolium castaneum (Coleoptera: Tenebrionidae) and Rhizopertha dominica (Coleoptera: Bostrichidae) in wheat. J. Econ. Entom., 83: 1677-1681.

\section{How to cite this article:}

Manohar Lal, Budhi Ram and Prabhat Tiwari. 2017. Botanicals to Cope Stored Grain Insect Pests: A Review. Int.J.Curr.Microbiol.App.Sci. 6(6): 1583-1594. doi: https://doi.org/10.20546/ijcmas.2017.606.186 